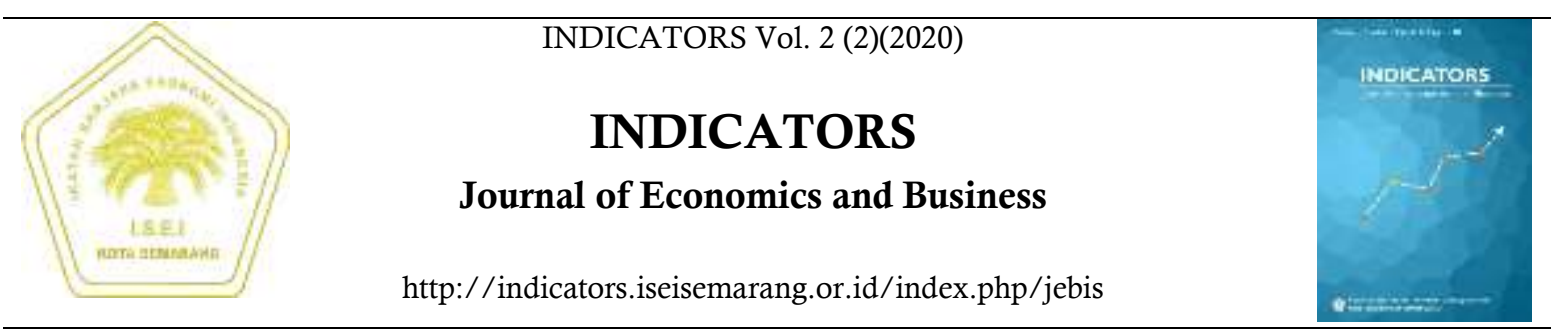

\title{
ANALISIS KINERJA KEUANGAN PEMERINTAH KOTA SEMARANG TAHUN 2013-2017
}

\author{
Efriyani Sumastuti ${ }^{1 凶}$, Eriza Nariyanti ${ }^{2}$, Ika Indriasari ${ }^{3}$
}

1,2,3 Universitas PGRI Semarang

Info Artikel

Sejarah Artikel:

Diterima Agustus 2020

Disetujui September 2020

Dipublikasikan

November 2020

Keywords: performance, financial ratios, Semarang city

\begin{abstract}
Abstrak
Kinerja keuangan pemerintah daerah merupakan ukuran yang digunakan untuk memastikan kemampuan daerah dalam menjalankan aturan pelaksanaan keuangan secara baik dan benar untuk mempertahankan layanan yang diinginkan. Penelitian ini bertujuan untuk menganalisis kinerja keuangan pemerintah daerah Kota Semarang dengan menggunakan 5 rasio keuangan. Data yang digunakan adalah data sekunder, berupa Laporan Realisasi Anggaran Pendapatan dan Belanja Daerah Kota Semarang pada tahun 2013-2017. Selanjutnya dilakukan perhitungan 5 rasio keuangan, yang terdiri dari rasio efektivitas, rasio efisiensi, rasio keserasian, rasio pertumbuhan dan rasio kemandirian. Hasil penelitian menunjukkan bahwa secara umum kinerja keuangan pemerintah daerah Kota Semarang sangat baik. Hal tersebut dapat dilihat dari rata-rata rasio efektivitas pendapatan asli daerah sangat efektif, rasio efisiensi keuangan daerah sangat efisien, rasio keserasian belanja operasi dengan belanja daerah, rasio pertumbuhan belanja operasi dan rasio pertumbuhan belanja modal mengalami pertumbuhan yang positif, rasio kemandirian yang sedang dengan pola hubungan partisipatif. Meskipun demikian perlu meningkatkan dan mengoptimalkan Pendapatan Asli Daerah (PAD) dari tahun ke tahun melalui pengendalian potensi-potensi baru daerah dan pengembangan potensi daerah
\end{abstract}

\begin{abstract}
The financial performance of local governments is a measure used to ensure the ability of the regions to properly and correctly enforce financial implementation rules to maintain the desired services. This study aims to analyze the financial performance of the local government of Semarang City using 5 financial ratios. The data used is secondary data, in the form of the Semarang City Regional Budget Realization Report in 2013-2017. Furthermore, 5 financial ratios are calculated, consisting of effectiveness ratios, efficiency ratios, compatibility ratios, growth ratios and independence ratios. The results showed that in general the financial performance of the Semarang City local government was very good. This can be seen from the effectiveness ratio of local revenue is very effective, the ratio of regional financial efficiency is very efficient, the ratio of operating expenditure to regional expenditure, the ratio of operating expenditure growth and the growth ratio of capital expenditure has positive growth, the ratio of self-reliance is moderate with participatory relationship patterns. Even so, it is necessary to increase and optimize Regional Original Income (PAD) from year to year through controlling new regional potentials and developing regional potential.
\end{abstract}

\footnotetext{
Alamat korespondensi:

Jl. Sidodadi Timur No 24, Dr Cipto Semarang

E-mail:efriyanisumastuti@upgris.ac.id
} 


\section{PENDAHULUAN}

Menurut Undang-Undang Nomor 23 Tahun 2014 tentang Pemerintahan Daerah, Undang-Undang Nomor 33 Tahun 2004 Tentang Perimbangan Keuangan antara Pemerintah Pusat dan Daerah serta UndangUndang Nomor 17 Tahun 2003 tentang Keuangan Negara menjelaskan APBD adalah wujud dari pengelolaan keuangan daerah. Penetapan dilakukan setiap tahun dengan peraturan daerah, terdiri atas Pendapatan, Belanja dan Pembiayaan. Dora (2017) menyatakan bahwa Peran pemerintah daerah dalam mengelola daerahnya sendiri merupakan tantangan yang harus diterima oleh pemerintah agar nantinya dapat membangun dan mengelola dengan baik daerahnya.

Dalam rangka untuk mengoptimalkan pelaksanaan otonomi, setiap daerah dituntut untuk lebih kreatif dan inovatif dalam perumusan kebijakan Pemerintah, khususnya bidang keuangan. Tim kerja pengelola Pendapatan Asli Daerah (PAD) untuk pembiayaan penyelenggaraan Pemerintah dan Pembangunan harus mampu untuk meningkatkan pertumbuhan di bidang ekonomi daerah (Rahmayati, 2016)

Mulyaningtyas (2018) menyatakan pemerintah daerah dalam berupaya meningkatkan kinerja keuangannya menggunakan konsep value for money, dimana mengandung arti dalam tiga elemen utama yaitu ekonomi, efisiensi dan efektivitas. Hal tersebut dapat menjadi sebuah petisi dari masyarakat kepada pemerintah daerah yang dapat mengelola suatu sumber-sumber keuangan asli daerah dengan baik. Rudianto (2013) dalam Wahyudi (2018) juga menyatakan bahwa kinerja keuangan merupakan suatu hasil yang dicapai oleh suatu perusahaan dalam mengelola aset perusahaan secara efektif selama periode tertentu. Di dalam sebuah perusahaan kinerja keuangan sangat dibutuhkan karena untuk mengetahui tingkat keberhasilan perusahaan terhadap aktivitas keuangan yang telah dilaksanakan.

Penjabaran mengenai pengelolaan keuangan ada di dalam suatu Anggaran
Pendapatan dan Belanja Daerah (APBD) baik secara langsung maupun tidak langsung yang dapat menggambarkan mengenai kemampuan Pemerintah Daerah dalam mendanai tugastugas pemerintah, pembangunan dan pelayanan sosial masyarakat. Anggaran Pendapatan dan Belanja Daerah (APBD) merupakan media kebijakan yang utama bagi Pemerintah Daerah (Syauqi, 2016) dalam Alvina (2018). Pengelolaan keuangan daerah tidak hanya memerlukan sumber daya manusia yang handal namun disisi lain dalam pengelolaan keuangan juga perlu adanya dukungan dari kemampuan keuangan yang memadai (Hakim, 2018).

Menurut Peraturan Pemerintah Republik Indonesia Nomor 58 Tahun 2005, tentang Pengelolaan Keuangan Daerah pada umumnya menjelaskan bahwa keuangan Daerah adalah semua hak dan kewajiban Daerah untuk penyelenggaraan Pemerintah Daerah yang dapat dinilai uang yang termasuk segala bentuk kekayaan suatu daerah. Kebijakan keuangan Daerah diarahkan untuk tercapainya sasaran pembangunan, menciptakan perekonomian daerah yang mandiri sebagai usaha bersama atas asas kekeluargaan berdasarkan demokrasi ekonomi yang berlandaskan Pancasila dan UndangUndang Dasar 1945 dengan peningkatan kemakmuran rakyat yang merata (Machhmud, 2014).

Analisis kinerja keuangan memiliki tujuan yaitu untuk mengukur dan mengevaluasi kinerja Pemerintah, mengukur kemampuan pendapatan dan sumber ekonomi, mengetahui kondisi keuangan, mengetahui kemampuan Pemerintah untuk memenuhi kewajibannya, dan mempercayai Pemerintah telah melaksanakan anggaran sesuai dalam peraturan perundang-undangan (Alvina, 2018).

Kinerja keuangan pemerintah daerah merupakan hal yang sangat penting untuk pemerintah dan pihak eksternal. Kinerja keuangan pemerintah daerah dapat dijadikan sebagai ukuran untuk kemampuan daerah dalam melaksanakan aturan pelaksanaan keuangan dengan baik dan benar untuk 
mempertahankan tujuan yang diinginkan, penilaian yang tinggi dapat dijadikan pegangan supaya pihak eksternal dapat berinvestasi di dalam daerah. Untuk melihat data pengukuran kinerja keuangan ada didalam informasi finansial yang diukur dengan anggaran-anggaran yang sudah dibuat sebelumnya dan dapat menjadi patokan untuk meningkatkan program selanjutnya dalam menghasilkan pelayanan publik yang baik dan berkualitas. (Tahir, 2019).

Sebagai Ibukota dan kota terbesar di Provinsi Jawa Tengah, kota Semarang menunjukkan perubahan yang signifikan dari pelayanan, penataan kota, dan pembangunannya. Selain dari faktor pemimpin daerahnya sendiri, faktor lain yang penting dalam mengukur kinerja pemerintah daerah yaitu dilihat dari kinerja keuangan Pemerintah Kota Semarang dalam mengalokasikan anggaran disegala sektor. Menurut Detiknews (2019) menyatakan bahwa keuangan pemerintah kota Semarang beberapakali mendapatkan predikat Wajar Tanpa Syarat (WTP) dari Badan Pemeriksa Keuangan (BPK) dari perwakilan Jawa Tengah dengan kriteria tertentu yang sudah di tentukan oleh BPK. Penelitian ini menggunakan metode penelitian kuantitatif dengan tujuan untuk mengetahui kinerja keuangan pemerintah daerah Kota Semarang tahun 2013-2017 dengan menggunakan beberapa rasio keuangan seperti Rasio Efektivitas Pendapatan Asli Daerah, Rasio Efisiensi Keuangan Daerah, Rasio Keserasian, Rasio Pertumbuhan dan Rasio Kemandirian.

Berdasarkan uraian diatas, penelitian ini bertujuan untuk menganalisis kinerja keuangan Pemerintah Kota Semarang dengan menggunakan data sekunder selama kurun waktu 5 tahun (2013-2017)

\section{METODE PENELITIAN}

Penelitian ini menggunakan metode penelitian kuantitatif deskriptif yang dilakukan dengan cara mengklasifikasikan, membandingkan dan menghitung data angka dengan menggunakan rumus-rumus yang sudah ditentukan. Data yang dianalisis bersifat data sekunder Time Series yang dilakukan dengan cara membandingkan rasio-rasio keuangan antara periode yang satu dengan periode yang lainnya dalam data laporan keuangan Pemerintah Daerah Kota Semarang tahun 2013-2017.

Untuk menganalisis kinerja keuangan digunakan variabel dan cara pengukuran seperti pada Tabel 1 .

Tabel 1. Variabel Penelitian

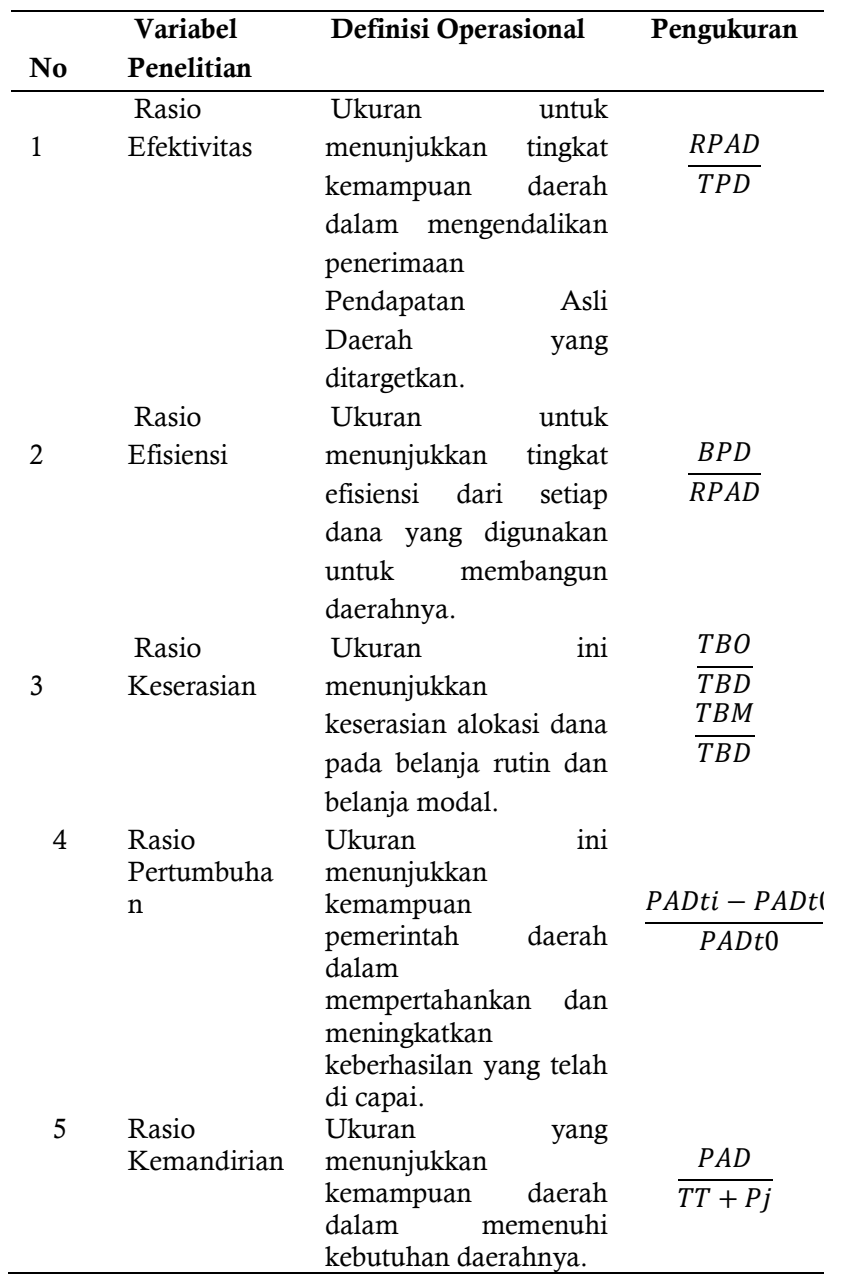

\begin{tabular}{|c|c|}
\hline \multicolumn{2}{|l|}{ Keter } \\
\hline RPAD & $\begin{array}{l}\text { : Total Realisasi Pendapatan } \\
\text { Asli Daerah }\end{array}$ \\
\hline PAD & $\begin{array}{l}\text { Total Pendapatan Asli } \\
\text { Daerah }\end{array}$ \\
\hline TPD & $\begin{array}{l}\text { : Total Target Penerimaan } \\
\text { Daerah }\end{array}$ \\
\hline BPD & $\begin{array}{l}\text { : Total Biaya Pemungutan } \\
\text { Daerah }\end{array}$ \\
\hline $\mathrm{TBO}$ & : Total Belanja Operasi \\
\hline TBD & : Total Belanja Daerah \\
\hline TBM & : Total Belanja Modal \\
\hline PADti & : Total PAD Tahun Ke i \\
\hline PADt0 & : Total PAD Tahun Sebelumny \\
\hline $\mathrm{TT}$ & : Total Transfer \\
\hline $\mathrm{Pj}$ & : Total Pinjaman \\
\hline
\end{tabular}


Jenis data yang diperlukan dalam penelitian ini adalah data sekunder, berupa Laporan Realisasi Anggaran Pendapatan dan Belanja Pemerintah Daerah Kota Semarang pada tahun 2013-2017.

\section{HASIL DAN PEMBAHASAN}

\section{Rasio Efektivitas, Efisiensi dan Keserasian}

Besarnya rasio efektivitas, efisiensi dan keserasian dapat dilihat pada Tabel 2. Untuk rasio keserasian dihitung dua rasio, yaitu rasio belanja operasi terhadap total belanja dan rasio rasio belanja modal terhadap total belanja.

Tabel 2. Rasio Efektivitas, Efisiensi dan

\section{Keserasian}

\begin{tabular}{ccccc}
\hline Tahun & $\begin{array}{c}\text { Rasio } \\
\text { Efektivitas } \\
\text { (\%) }\end{array}$ & $\begin{array}{c}\text { Rasio } \\
\text { Efisiensi } \\
\mathbf{( \% )}\end{array}$ & $\begin{array}{c}\text { sio TBO } \\
\text { terhada } \\
\mathbf{p} \text { TBD } \\
\mathbf{( \% )}\end{array}$ & $\begin{array}{c}\text { Rasio } \\
\text { TBM } \\
\text { terhadap } \\
\text { TBD } \\
\text { (\%) }\end{array}$ \\
\hline 2013 & 118,88 & 11,10 & 76,07 & 23,89 \\
2014 & 129,94 & 9,71 & 72,88 & 27,06 \\
2015 & 112,42 & 7,35 & 42,60 & 22,69 \\
2016 & 111,56 & 8,26 & 73,82 & 26,11 \\
2017 & 105,87 & 4,79 & 70,53 & 29,47 \\
Rata-rata & $\mathbf{1 1 5 , 7 4}$ & $\mathbf{8 , 2 4}$ & $\mathbf{6 7 , 1 8}$ & $\mathbf{2 5 , 8 4}$ \\
\hline
\end{tabular}

Dari tabel 2 diketahui bahwa efektivitas Pendapatan Asli Daerah mengalami fluktuasi (tidak stabil), dengan nilai rata-rata rasio efektivitas PAD adalah $115,74 \%$. Tingkat persentase yang paling kecil yaitu pada tahun 2017 dengan jumlah persentase yaitu $105,87 \%$, dan persentase tingkat efektivitas PAD paling besar yaitu pada tahun 2014 dengan jumlah persentase yaitu $129,94 \%$. Nilai diatas $100 \%$ artinya pemerintah Daerah Kota Semarang dalam merealisasikan Pendapatan Asli Daerah sangat baik. Dengan demikian, dapat disimpulkan bahwa pengelolaan pendapatan asli daerah Kota Semarang sudah sangat efektif.

Hasil analisa pada tahun 2013 menunjukkan persentase yaitu $118,88 \%$, pada tahun 2014 persentase mengalami kenaikan yaitu $129,94 \%$, pada tahun 2015 persentase mengalami penurunan yaitu $112,42 \%$, pada tahun 2016 dan 2017 persentase juga mengalami penurunan yaitu $111,56 \%$ dan
$105,87 \%$. Penurunan terhadap persentase pada tahun 2013-2017 disebabkan karena penerimaan dari sektor pajak dan retribusi daerah lebih rendah dari yang dianggarkan sebelumnya. Tolok ukur tingkat Efektivitas Pendapatan Asli adalah: sangat efektif $>100 \%$; efektif $=100 \%$; cukup efektif $=$ 90\%-99\%; kurang Efektif $=\quad 75 \%-89 \%$ dan tidak efektif $<75 \%$.

Tingkat efisiensi pemerintah daerah dalam biaya pemungutan Pendapatan Asli daerah atau biasa disebut dengan pendapatan retribusi daerah relatif kurang stabil. Persentase paling tinggi terjadi pada tahun 2013 yaitu $11,10 \%$ dan persentase paling rendah terjadi pada tahun 2017 yaitu 4,79\%. Secara umum, persentase rata-rata pada rasio efisiensi menunjukkan angka kurang dari 10\%, artinya bahwa pengelolaan Pendapatan Asli Daerahnya sudah sangat efisien.

Rasio efisiensi pemerintah daerah Kota Semarang tahun 2013-2017 menunjukkan terjadi perubahan yang berfluktuasi, dan secara keseluruhan dari tahun tersebut rasio efisiensi keuangan daerah termasuk dalam ketegori sangat efisien itu artinya seluruh persentase rasio efisiensi keuangan daerah berada di bawah 10\%. Pada tahun 2013 persentasenya yaitu $11,10 \%$ karena hasil persentase di atas $10 \%$ itu disebabkan karena kurang terealisasinya anggaran pendapatan asli daerah. Pada tahun 2014 persentasenya yaitu $9,71 \%$, pada tahun 2015 persentasenya turun yaitu 7,35\%, pada tahun 2016 persentase naik yaitu $8,26 \%$, dan pada tahun 2017 persentase kembali turun yaitu 4,79\%. Namun, naik-turunnya persentase tersebut masih dalam kategori efisien, menurunnya persentase juga disebabkan karena penerimaan retribusi daerah lebih rendah dari yang dianggarkan sebelumnya.

Tolok ukur kriteria Tingkat Efisiensi pada keuangan daerah adalah sangat efisien $<10 \%$; efisien $=10 \%-20 \%$; cukup efisien $=$ $21 \%-30 \%$; kurang efisien $=31 \%-40 \%$ dan tidak efisien $>40 \%$

Persentase rata-rata tingkat belanja operasi terhadap total belanja yaitu sebesar $67,18 \%$. Rasio belanja operasi terhadap total 
belanja paling tinggi terjadi pada tahun 2013 yaitu $76,07 \%$ dan belanja operasi terhadap total belanja paling rendah terjadi pada tahun 2015 yaitu 42,60\%. Secara umum rasio keserasian belanja operasi terhadap belanja daerah menunjukkan angka sekitar 60-90\%, artinya pengelolaan keuangan pemerintah daerah Kota Semarang menunjukkan keserasian antara belanja operasi dengan belanja daerah.

Rasio belanja operasi terhadap total belanja memperlihatkan persentasenya berfluktuasi pada tahun 2013-2017. Pada tahun 2013 persentasenya yaitu $76,07 \%$, pada tahun 2014 dan 2015 persentase mengalami penurunan yaitu $72,88 \%$ dan $42,60 \%$, pada tahun 2016 persentase naik yaitu 73,82\%, dan pada tahun 2017 mengalami penurunan persentase yaitu $70,53 \%$. Persentase turun disebabkan karena realisasi Belanja Operasi lebih rendah dari tahun sebelumnya, seperti belanja pegawai, belanja bunga, belanja subsidi, dan belanja operasi lainnya. Kriteria proporsi tingkat rasio keserasian pada rasio belanja operasi terhadap belanja daerah yaitu sekitar 60\%-90\%. Rata-rata persentase dari rasio ini adalah $67,18 \%$, karena hasil tersebut menunjukkan angka sekitar $60-90 \%$ itu artinya secara keseluruhan dari tahun 2013-2017 pengelolaan keuangan pemerintah daerah Kota Semarang menunjukkan adanya keserasian antara Belanja Operasi terhadap Belanja Daerah.

Persentase rata-rata tingkat belanja modal terhadap total belanja yaitu $25,84 \%$. Belanja operasi terhadap total belanja persentase paling tinggi terjadi pada tahun 2017 yaitu 29,47\% dan belanja modal terhadap total belanja persentase paling rendah pada tahun 2015 yaitu $22,69 \%$. Pada rasio belanja modal terhadap belanja daerah persentasenya mengalami fluktuasi (tidak stabil). Pada tahun 2015 persentasenya turun yang awalnya $27,06 \%$ menjadi $22,69 \%$. Penurunan persentase disebabkan karena pada realisasi Balanja Modal lebih rendah dari tahun sebelumnya, seperti belanja tanah, belanja peralatan dan mesin, belanja gedung dan bangunan dan belanja modal lainnya.
Secara umum rasio keserasian belanja modal terhadap belanja daerah menunjukkan angka diatas $20 \%$ itu artinya pengelolaan keuangan pemerintah daerah Kota Semarang pada belanja modal dengan belanja daerah memiliki keserasian.

\section{Rasio Pertumbuhan dan Kemandirian}

Hasil perhitungan rasio pertumbuhan dan kemandirian pemerintah daerah Kota Semarang dapat dilihat pada tabel 3 .

Tabel 3. Rasio Pertumbuhan dan Kemandirian

\begin{tabular}{cccccc}
\hline Tahun & $\begin{array}{c}\text { Rasio } \\
\text { Pertumb } \\
\text { uhan } \\
\text { PAD } \\
\mathbf{( \% )}\end{array}$ & $\begin{array}{c}\text { Rasio } \\
\text { Pertumbu } \\
\text { han } \\
\text { Pendapata } \\
\mathbf{n}\end{array}$ & $\begin{array}{c}\text { Rasio } \\
\text { Pertumbu } \\
\text { han } \\
\text { Belanja } \\
\text { Operasi } \\
\text { (\%) }\end{array}$ & $\begin{array}{c}\text { Rasio } \\
\text { Pertumbu } \\
\text { han } \\
\text { Belanja } \\
\text { Modal (\%) }\end{array}$ & $\begin{array}{c}\text { Remasio } \\
\text { irian } \\
\mathbf{( \% )}\end{array}$ \\
\hline 2013 & 40,21 & 26,92 & 59,02 & $-41,50$ & 51,79 \\
2014 & 22,94 & 13,21 & 14,55 & 35,39 & 59,14 \\
2015 & 5,55 & 5,72 & $-36,73$ & 129,59 & 97,97 \\
2016 & 24,14 & 22,59 & 112,82 & $-44,11$ & 71,98 \\
2017 & 20,13 & $-3,38$ & 5,18 & 197,31 & 82,47 \\
$\begin{array}{c}\text { Rata- } \\
\text { rata }\end{array}$ & 22,60 & 13,01 & 30,97 & 55,34 & 72,67 \\
\hline
\end{tabular}

Tabel 3 menunjukkan bahwa :

a. Rasio Pertumbuhan Pendapatan Asli Daerah

Persentase rata-rata pada rasio pertumbuhan Pendapatan Asli Daerah pemerintah daerah Kota Semarang pada tahun 2013-2017 yaitu $22,60 \%$, itu artinya terjadi pertumbuhan positif dan menunjukkan bahwa terjadi peningkatan kinerja keuangan Pendapatan Asli Daerah pemerintah daerah Kota Semarang. Persentase paling tinggi pada tahun 2013 yaitu $40,21 \%$ dan persentase terendah pada tahun 2015 yaitu 5,5\%.

Rasio pertumbuhan pendapatan asli daerah pada tahun 2013 persentasenya yaitu 40,21\%, pada tahun 2014 dan 2015 persentasenya mengalami penurunan yaitu $22,94 \%$ dan $5,55 \%$, pada tahun 2016 persentase mengalami kenaikan yaitu $24,14 \%$ dan pada tahun 2017 persentase kembali mengalami penurun yaitu $20,13 \%$. Penurunan persentase dari tahun ke tahun disebabkan Realisasi Pendapatan Asli Daerah lebih rendah dari tahun sebelumnya. 


\section{b. Rasio Pertumbuhan Pendapatan}

Rasio pertumbuhan pendapatan Asli Daerah dari tahun 2013-2017 menunjukkan bahwa pertumbuhan yang berfluktuasi. Pada tahun 2013 persentasenya yaitu $26,92 \%$, pada tahun 2014 dan 2015 mengalami penurunan yaitu $13,21 \%$ dan $5,72 \%$, pada tahun 2016 persentasenya mengalami kenaikan yaitu $22,59 \%$ dan pada tahun 2017 persentase mengalami penurunan yaitu $-3,38 \%$. Pertumbuhan yang negatif pada tahun 2017 tersebut disebabkan karena sebagian besar pendapatan mengalami pertumbuhan negatif seperti pendapatan transfer pemerintah pusatdana perimbangan, pendapatan transfer pemerintah pusat-lainnya, transfer pemerintah provinsi, dan lain-lain pendapatan yang sah. Secara keseluruhan, pertumbuhan pendapatan pemerintah daerah Kota Semarang tahun 2013-2017 mengalami pertumbuhan positif dengan persentase rata-rata yaitu $13,01 \%$.

c. Rasio Pertumbuhan Belanja Operasi

Rasio pertumbuhan belanja operasi pada tahun 2013-2017 berfluktuasi. Pada tahun 2016, persentase pertumbuhan belanja operasi paling tinggi yaitu $112,82 \%$ dan persentase terendah terjadi pada tahun 2015 yaitu $-36,73 \%$. Pertumbuhan negatif ini disebabkan karena sebagian besar belanja operasi mengalami pertumbuhan negatif, seperti belanja pegawai, belanja bunga, belanja subsidi, belanja hibah, dan belanja operasi lainnya. Secara keseluruhan pertumbuhan belanja operasi dari tahun 2013-2017 mengalami pertumbuhan yang positif yaitu dengan persentase rata-rata yaitu $30,97 \%$.

Pada tahun 2013 persentasenya yaitu $59,02 \%$, pada tahun 2014 dan 2015 persentasenya mengalami penurunan yaitu $14,55 \%$ dan $-36,73 \%$, pada tahun 2016 persentase mengalami kenaikan yaitu $112,82 \%$ dan pada tahun 2017 persentase mengalami penurunan yaitu $5,18 \%$. Pertumbuhan negatif pada tahun 2015 tersebut disebabkan karena sebagian besar belanja operasi mengalami pertumbuhan yang negatif, seperti belanja pegawai, belanja bunga, belanja subsidi, belanja hibah dan belanja operasi lainnya.

\section{d. Rasio Pertumbuhan Belanja Modal}

Tabel 2 menunjukkan bahwa rasio pertumbuhan belanja modal dengan persentase paling tinggi pada tahun 2017 yaitu $197,31 \%$ dan persentase terendah pada tahun 2013 yaitu $-41,50 \%$, pertumbuhan negatif pada tahun 2013 dan 2016 disebabkan karena sebagian besar belanja modal mengalami pertumbuhan negatif seperti belanja tanah, belanja peralatan dan mesin, belanja gedung dan bangunan, belanja jalan, irigasi, dan jaringan dan belanja modal yang lainnya. Secara keseluruhan pertumbuhan belanja modal dari tahun 2013-2017 mengalami pertumbuhan yang positif yaitu dengan ratarata $55,34 \%$.

Pada tahun 2014 dan 2015 persentase mengalami kenaikan yaitu $35,39 \%$ dan $129,59 \%$, pada tahun 2016 persentase mengalami penurunan yaitu $-44,11 \%$ dan pada tahun 2017 persentase kembali naik yaitu 197,31\%. Pertumbuhan negatif pada tahun 2013 dan 2016 disebabkan karena sebagian besar belanja modal mengalami pertumbuhan yang negatif, seperti belanja tanah, belanja peralatan dan mesin, belanja gedung dan bangunan, belanja jalan, irigrasi, dan jaringan, dan belanja modal yang lainnya.

e. Rasio Kemandirian Keuangan Daerah

Rasio kemandirian keuangan daerah

Kota Semarang mengalami fluktuasi. Persentase paling tinggi pada tahun 2015 yaitu 97,97\%, dan persentase paling rendah pada tahun 2013 yaitu 51,79\%. Hal ini menunjukkan bahwa pengelolaan keuangan daerah Kota Semarang menunjukkan tingkat kemandirian sedang dengan pola hubungan partisipatif. Pada tahun 2014 dan 2015 persentase meningkat yaitu $59,14 \%$ dan $97,97 \%$, pada tahun 2016 persentase menurun $71,98 \%$, dan pada tahun 2017 persentase naik menjadi $82,47 \%$. Turunnya persentase disebabkan karena tingkat ketergantungan daerah terhadap bantuan pihak ekternal (pusat dan provinsi) pada tahun itu lebih tinggi dari pada tahun yang lain.

Tolok ukur kriteria tingkat kemandirian keuangan daerah adalah rendah sekali $=0 \%$ $25 \%$ (Instruktif); $\quad$ rendah $=26 \%-50 \%$ 
(konsultatif); sedang $=51 \%-75 \%$ (partisipatif); tinggi $=76 \%-100 \%$ (delegatif). Rata-rata persentase pada rasio kemandirian yaitu $72,67 \%$. Secara keseluruhan pada rasio kemandirian keuangan daerah Kota Semarang masih termasuk kedalam kategori sedang dengan pola hubungan partisipatif.

\section{SIMPULAN}

Secara umum kinerja keuangan pemerintah Kota Semarang sangat baik. Hal tersebut dapat dilihat dari rata-rata rasio efektivitas pendapatan asli daerah sangat efektif, rasio efisiensi keuangan daerah sangat efisien, rasio keserasian belanja operasi dengan belanja daerah, rasio pertumbuhan belanja operasi dan rasio pertumbuhan belanja modal mengalami pertumbuhan yang positif, rasio kemandirian yang sedang dengan pola hubungan partisipatif. Meskipun demikian perlu meningkatkan dan mengoptimalkan Pendapatan Asli Daerah (PAD) dari tahun ke tahun melalui pengendalian potensi-potensi baru daerah dan pengembangan potensi daerah.

\section{DAFTAR PUSTAKA}

Bisma, I Dewa Gde dan Hery Susanto. 2010. Evaluasi Kinerja Keuangan Daerah Pemerintah Provinsi Nusa Tenggara Barat Tahun Anggaran 2003-2007. Genec Swara Edisi Khusus Vol. 4 No. 3, Desember 2010.

BPS Kota Semarang. (2018). Produk Domestik Regional Bruto Kota Semarang Menurut Lapangan Usaha Tahun 2013-2017. Semarang.

Hakim, M. F. (2018). Analisis kinerja keuangan pada pemerintah Daerah Kabupaten Sleman Tahun Anggaran 2010-2016.

Fahmi, Irham. (2017). Analisis Kinerja Keuangan. Alfabeta:Bandung

Kaunang, C. E. (2016). Analisis Kinerja Pengelolaan Keuangan Daerah Dan Tingkat Kemandirian Daerah Di Era Otonomi Daerah: Studi Pada Kota Manado (Tahun 2010-2014). Jurnal Berkala Ilmiah Efisiensi, 16(2).

Machmud, M. (2014). Analisis Kinerja Keuangan Daerah Di Provinsi Sulawesi Utara Tahun 2007-2012. Jurnal berkala ilmiah efisiensi, 14(2).
Mahmudi. (2016). Analisis Laporan Keuangan Pemerintah Daerah. UPP STIM YKPN: Yogyakarta.

Mulyanigtyas, M. (2018). Analisis Kinerja Keuangan Kota Mojokerto Dengan Pendekatan Value For Money. PRIVE: Jurnal Riset Akuntansi dan Keuangan, 1(1), 1-14.

Pemerintah Kota Semarang. (2013). Laporan Keterangan Pertanggungjawaban Kota Semarang tahun 2013.

(2014). Laporan Keterangan Pertanggungjawaban Kota Semarang tahun 2014.

(2015). Laporan Keterangan Pertanggungjawaban Kota Semarang tahun 2015.

(2016). Laporan Keterangan Pertanggungjawaban Kota Semarang tahun 2016.

(2017). Laporan Keterangan Pertanggungjawaban Kota Semarang tahun 2017.

Rahmayati, A. (2016). Analisis Kinerja Keuangan Pemerintah Daerah Kabupaten Sukoharjo Tahun Anggaran 2011-2013. EKA CIDA, 1(1).

Sugiyono. (2018). Metode Penelitian Kuantitatif. Bandung:Alfabeta.

Suprantiningrum, S. R. (2016). Analisis Kinerja Pengelolaan Keuangan Daerah Dan Tingkat Kemandirian Daerah Di Era Otonomi Daerah (Studi Kasus Kota Semarang Tahun 2009. 2013). Media Ekonomi dan Manajemen, 30(1).

Suranta, S., Perdana, H. D., \& Syafiqurrahman, M. (2017). Analisis Kinerja Keuangan Pemerintah Daerah: Studi Komparasi Propinsi Jawa Tengah dan Kalimantan Selatan. Jurnal Akuntansi, 5(2), 111-124.

Tahir, I., Mas'ud, M., \& Plyriadi, A. (2019). Faktorfaktor yang mempengaruhi kinerja keuangan daerah pada badan pengelolaan keuangan dan aset daerah kota makassar. ISSN2089-0982, Hal 61-70

Tama, A. I. (2015). Analisis Kinerja Keuangan Pemerintah Daerah melalui Analisis Rasio Keuangan APBD Kabupaten/kota di Indonesia Sebelum dan Sesudah Penerapan Undangundang Nomor 28 Tahun 2009. JRAK: Jurnal Riset Akuntansi dan Komputerisasi Akuntansi, 6(2), 20-32. 
Eriza N., Efriyani S. , Ika I. / INDICATORS Journal of Economics and Business Vol. 2 (2)(2020)

Wahyudi, R., Thoyib, M., \& Sriwijaya, D. J. A. P. N. (2015). Analisis kinerja keuangan dengan metode economic value added (eva) dan q-tobin pada pt.(persero) pupuk sriwidjaja palembang. Jurnal Akuntanika,Vol. 4 No. 1, Januari-Juni 2018.

Wonda, W. (2016). Analisis Kinerja Keuangan Pemerintah Daerah Dalam Masa Otonomi Daerah Kabupaten Nabire Provinsi Papua. Jurnal EMBA: Jurnal Riset Ekonomi, Manajemen, Bisnis dan Akuntansi, 4(3). 